\title{
The Role of the European Union in Conflict Resolution
}

\section{President Martti Ahtisaari}

\author{
Taken from the Iveagh House lecture, delivered at the Department of Foreign Affairs \\ and Trade, Dublin, Ireland September 6, 2017
}

Excellencies, ladies and gentlemen, dear friends,

As always, it is a great pleasure to be here in Ireland. I am also pleased to have is opportunity to discuss with you, colleagues from across Europe, the role of the European Union on the global scene at this particular time, when the global political order is undergoing significant shifts. Shifts that will affect the place and role of the European Union in international affairs.

The title of my lecture is "The Role of the European Union in Conflict Resolution". However, I feel limiting my presentation to conflict resolution in its narrow definition would not make justice to the breadth of the EU's contributions to peace and stability. It would also prevent us from recognising and assessing the full scope of meaningful ways the EU can support conflict prevention and resolution in the future.

Therefore, I have taken the liberty to expand the topic. I will offer some broad reflections on the role of the European Union in advancing peace and stability, both inside and outside its borders.

When talking about conflict prevention and resolution, we instinctively think about areas beyond the European borders. At the same time, we tend to forget the political will and efforts that were and are required to create and maintain stability and peace in Europe.

Dear friends, I believe few disagree with the assessment that increased integration of national economies and political systems have helped keep conflict at bay and foster co-operation between the EU member states in the past. What is increasingly questioned is whether the claim still holds true today, over 70 years since the end of the Second World War and over 60 years since the creation of the European Union's forerunner. I argue it does.

According to the 2017 Global Peace Index, Europe remains the most peaceful region in the world. Eight of the ten most peaceful countries worldwide are European. While the EU is not the only reason for the high level of stability, it certainly deserves some credit for this achievement.

The EU framework enables and encourages regular contact, negotiation and co-operation between the member states. It provides a platform to discuss a broad range of issues - including highly 
contested ones - in a constructive manner.

In other words, instead of the mere absence of war, generally referred to as "negative peace", the EU has been able to advance "positive peace" within and between European countries. That is, it has strengthened attitudes and institutions that favour co-operation. It has created conditions where the use of force to resolve disputes has become unthinkable. These effects have certainly been visible here in Ireland, and I sincerely hope the achievements and the EU's support for the Northern Ireland peace process will not be endangered by Brexit.

Dear friends, the reason why I want to draw your attention to the EU's role in this continent is that these days many Europeans take peace for granted. The danger lies in that the more taken-forgranted something becomes, the less important active measures to protect it are considered. Therefore, it is critical to recognise the EU's contribution to creating and maintaining peace between European countries. It is also important to identify the elements that have enabled it to play a positive role. Those features and methods need to be consolidated for the EU to continue to serve as a conflict prevention and resolution mechanism inside Europe. I encourage you to take an active role in this.

Recently, we have witnessed the emergence of forces that challenge the principles and values at the heart of the European Union. The rise of nationalism, growing isolationist sentiments and increasing calls for strong leaders appear to be questioning the very foundations of the European political order.

Let me cite here the Article 1 of the Lisbon treaty: "The European Union is founded on the values of respect for human dignity, freedom, democracy, equality, the rule of law and respect for human rights, including the rights of persons belonging to minorities. These values are common to the Member States in a society in which pluralism, non-discrimination, tolerance, justice, solidarity and equality between women and men prevail."

My years as a peace mediator have taught me that the only way to build and sustain peaceful societies is for those societies to actively work for democracy, human rights, equality and the rule of law. There is no shortcut. A commitment to these same values has helped maintain peace in Europe for decades. It is therefore particularly saddening to see that some fellow Europeans seem now to be ready to compromise them. If the values and principles are no longer seen as worth striving for, my concern is that we are going to see increased political tensions in Europe in the not-too-distant future.

Dear friends, we should read Brexit, opposition to immigration and the rise of nationalist and populist voices as early warning signs. What combines these developments is a turn inwards, a perception of a nation state as a safe haven from a world of uncertainty. Some have suggested that reliance on nation states results from the fact that many Europeans no longer see the EU as relevant. They do not see the $\mathrm{EU}$ as capable of responding to their concerns and protecting their interests. If this is the case, it certainly should not have come to us, the European political elite, as a surprise. It nevertheless did.

A recently published Chatham House report "The Future of Europe" provides one explanation why. Among the main findings was that there is a wide divide between elites and the public in general attitudes, beliefs and experiences related to the EU. Elites are more likely to experience the benefits of the European integration and are generally more liberal and optimistic. Meanwhile, large sections of the 
public view the EU in negative terms. They want to see the EU return some powers to member states and feel anxious over the effects of immigration. This gap may explain why many of us did not realise that the commitment to the "European project" had weakened and was less widely shared as we thought. Not until Brexit and other clear signs of dissatisfaction.

Dear friends, now is the time to consider, what could be done to rebuild commitment to our joint values and European co-operation. For, regardless of the EU's flaws, they are the best guarantees we have for peace in Europe.

As a starting point, we need to recognise that neither the EU nor the underlying values are sustained without political efforts. The political elite and the EU member states have to figure out how to build a union that is more responsive to citizens' concerns. This requires a better and genuine understanding of people's perceptions and priorities, and courage to adjust the existing system based on them.

It is critical to remember that the core values of the EU are not just Europe's values. Neither are they distinctively Western. They are first and foremost global. And all member states of the United Nations have committed themselves to living up to these values. As the Article 1 of the Charter of the United Nations says: "to maintaining international peace and security, and to that end: to taking effective collective measures for the prevention and removal of threats to the peace, and for the suppression of acts of aggression or other breaches of the peace, and to bringing about by peaceful means, and in conformity with the principles of justice and international law."

I wonder if references to democracy, human rights and rule of law as "Western" may have indeed created an opportunity for their disregard in some parts of the world.

I have so far talked about the dynamics at play within the European Union, as the EU's role in conflict resolution is shaped at least as much by internal factors as external ones. Now, let me move on to the EU's role in conflict resolution outside its borders.

Before the 2008 financial crisis, many believed European countries were on a path towards an "ever closer union". The same optimism was visible in perceptions about the EU's role in external relations at the time. The EU was described as a "normative" or "ethical power". Its "soft power" was seen as counterbalancing the "hard power" of the United States.

What unified these perceptions was the idea that the EU shapes the international relations not so much through its actions, but by the virtue of its existence. Member states' common commitment to the EU's norms and values, and their consistent application inside and outside the EU, were considered to be at the core of the union's normative power.

Since then, European optimism has diminished and been replaced with what in my view is healthy realism. This shift is visible in the EU's recent Global Strategy for Foreign and Security Policy. It looks at the European Union and the surrounding world as they are, not as we would like them to be. I have always believed that if one wants to practice sustainable and effective politics, the key precondition is to be honest - about realities, about oneself. The Global Strategy is thus a good starting point for planning and implementing policies that advance the interests of the EU and the wider world. 
Dear friends, declarations and strategies do not, however, lead to concrete actions without political will.

According to the Lisbon treaty, the EU seeks to "advance in the wider world democracy, the rule of law, the universality and indivisibility of human rights and fundamental freedoms, respect for human dignity, the principles of equality and solidarity, and respect for the principles of the United Nations Charter and international law. [...] It shall promote multilateral solutions to common problems, in particular in the framework of the United Nations."

Unfortunately, the actions of the EU and its member states send a very different message. I am particularly disappointed at the way Europe has dealt with the migration issue. The member states have failed to develop a common response when it is urgently needed. Instead of searching for collective solutions, European countries have favoured short-term responses and measures that are believed to protect national interests.

Yet, it is clear strengthening borders and refusing burden-sharing neither serve our interests, nor protect the human rights and dignity of migrants. It is equally clear such measures are not sustainable. Conflicts that are currently forcing people to leave their homes will take years if not decades to bring to an end. There are no quick fixes to crises in places such as Syria, Iraq and Afghanistan.

Dear friends, the European Union has a significant potential to contribute to resolving conflicts outside its borders. I think, however, that this potential has not been fully utilised.

The EU has the capacities, expertise and resources to support conflict resolution if there is political will to do so. The EU and its member states have a broad spectrum of tools available. These include traditional diplomacy and foreign policy, trade policy and development assistance. This is an asset not only in assisting conflict parties to address the immediate causes of conflict but also in tackling more structural issues.

I have personally seen this in Aceh, Indonesia where I was invited to mediate between the Indonesian government and the separatist Free Aceh Movement. The European Union provided important funding for the talks. At the same time, it supported the humanitarian efforts in the aftermath of the 2004 tsunami. After 7 months of peace talks in Finland, a Memorandum of Understanding was signed between the parties in 2005. The EU together with 5 ASEAN counties took a central role in the monitoring of the peace process. For me, the EU's comprehensive and flexible support during the different stages of the Aceh peace process is a good example of the significant role the EU can play in conflict resolution.

Dear friends, the shifts in the global political order that I mentioned at the start of my speech have made the EU's active role on the global scene all the more critical. The isolationist tendencies in the US policy have opened a space for the EU to assume a greater role. More importantly, they have left the EU with responsibility to do so.

I am convinced that European countries can best serve their interests through multilateral actions, both as part of the European Union and the United Nations. Just as the EU can function only if the member states have enough political will, the UN can prove its relevance only if it is given a chance to take action when needed. The UN Security Council members have a special responsibility in ensuring the 
UN can fulfil its mandate and promote peace worldwide.

Dear friends, today it would be easy to say that we live in a chaotic and unpredictable world. True. But when you reach my age you see the world has always been unpredictable. Our joint history and shared values are much stronger than we think. But they are not self-sustained. European countries and citizens need to co- operate in defending those principles and values now more than ever. That is a prerequisite for Europe's effective role in building and maintaining peace, inside and outside its borders.

Martti Oiva Kalevi Ahtisaari is a Finnish politician, the tenth President of Finland, Nobel Peace Prize laureate and United Nations diplomat and mediator, noted for his international peace work. Ahtisaari founded the Crisis Management Initiative (CMI) and has had a number of diplomatic roles, including acting as an arms inspector in Northern Ireland. He made a major contribution to the difficult negotiations which led to Namibian independence in 1989-90. He arbitrated in Kosovo in 1999 and 2005-07, and helped to bring the long-lasting conflict in the Aceh province in Indonesia to an end in 2005. 